\title{
THE STATE OF THE OPTICAL DENSITY OF THE ALVEOLAR PROCESS OF THE JAWS OF RATS IN SUPRAOCCLUSIVE RELATIONSHIPS OF INDIVIDUAL TEETH IN THE AGE ASPECT
}

DOI: $10.36740 /$ WLek202108104

\author{
Yurii V. Lakhtin, Serhii M. Zviahin, Lidia M. Karpez \\ SUMY STATE UNIVERSITY, SUMY, UKRAINE
}

\begin{abstract}
The aim of the study was to conduct a comparative assessment of the optical density of bone tissue of the alveolar process of the jaws of rats in supraocclusive relationships of individual teeth in the age aspect.

Materials and methods: The study was performed on 60 white laboratory rats. Rats were divided into control (30 individuals) and experimental (30 individuals) groups. According to the age of rats each group was divided into 3 subgroups ( 10 animals): young, mature and senile. In the experimental group, the state of supraocclusion was modeled by increasing the height of the lower right second molars placing a seal $1 \mathrm{~mm}$ high. Experimental animals were removed from the experiment on the 15th day through decapitation. The lower jaws were skeletonized, jaw blocks were sawn in the molar area. Bone mineral density was determined using optical densitometry. The statistical processing defined the average $(M)$ and its error $(m)$. The statistical significance of the difference in two independent groups was performed according to nonparametric criteria (Mann-Whitney U-test and W-Wilcoxon test). Statistical processing was conducted with the help of integrated package of statistical program AtteStat 12.0.5 for MS Excel. Differences at $p \leq$ 0.05 were considered statistically significant.

Results: Statistical discrepancy is present in rats of mature and senile age, as well as between the indicators of all rats of the control and experimental groups ( $\leq 0.05)$. No significant difference was observed in young rats, but the indicators of the experimental group were $3.82 \%$ worse than in the control group. In senile rats, the density of the alveolar process decreased by $26.6 \%$, in adult rats by $17.5 \%$.

Conclusions: The presence of supraocclusive relationships of individual teeth causes a decrease in bone density of the alveolar process of the jaws in rats. The greatest loss of density among age groups in elderly rats.
\end{abstract}

KEY WORDS: traumatic occlusion, rats, supraocclusion, densitometry

Wiad Lek. 2021;74(8):1800-1803

\section{INTRODUCTION}

The function of the dental system is provided by a certain structure consisting of a complex of tissues. These tissues are functionally and morphologically related to each other and form a complex called periodontal. During chewing, this complex is subjected to high pressure, which is transmitted through the tooth to all structural components of the periodontium - periodontium, alveolar process of the jaw, buttresses of the jaw, temporomandibular joint. Under normal conditions, periodontal tissues can withstand such a masticatory load. The compensatory capabilities of the periodontium provide resistance to forces that exceed the physiological load. The periodontium is able to withstand strong, but short-term overload without morpho-functional changes in the tissues. If the load disappears quickly, which usually happens during chewing, then all the changes in the periodontium are reversible. However, a weak but long-lasting masticatory load, depletes the reserve capacity of the periodontium, reduces its protective and compensatory mechanisms, which leads to a violation of the integrity of the entire periodontal complex. In this case, the tooth is displaced, which causes deformation of the periodontal ligament with the formation of overload zones at the junction of the ligament and the inner cortical plate of the dental alveolus, forming zones of resorption or opposition of the alveolar part of the jaw. This condition is called traumatic occlusion (TO) $[1,2]$. According to some researchers, the movement of teeth and deformation of bone tissue under excessive masticatory load is an adaptive response to avoid irreversible damage to teeth [3]. The reason for TO may be increased fillings in the teeth or dentures, parafunctional habits, orthodontic pathology [4]. One of the factors of TO is the state of supraocclusion, in which the cutting edge or the masticatory surface of a group of teeth or individual teeth are located above the occlusal plane. Supraocclusion of teeth can be a symptom of various orthodontic pathology.

According to the literature, patients with underdevelopment of the jaw bones and crowded teeth show preclinical signs of periodontal disease accompanied by persistent vasoconstriction and impaired microcirculation in tissues and reduced quality of bone tissue (total mineral density, elasticity, spatial structure and spatial disorientation) [5]. This explains the data that indicate that periodontal tissue 
pathology in patients with dental anomalies is twice as common as in people without such anomalies [6]. It is believed that excessive occlusal forces are not the main cause of periodontal pathology, they can act as a cofactor in the pathogenesis of periodontitis [7]. Interocclusal disorders in the dental system complicate the development of periodontal pathology, sometimes occlusive trauma can lead to exclusively local disorders of microcirculation in the periodontal ligament and the progression of destructive processes in the supporting tissues. As a result, there is a situation when even a normal occlusal load becomes traumatic, causing pathological migration of teeth $[6,8]$.

The reaction of the periodontal complex to the functional load is explained in different ways. It is believed that the key component in this regard is the periodontal ligament, and the role of bone tissue in the alveolar process is less clearly defined [3]. The analysis of publications on studies studying the reactions of bone tissue of the alveolar process in supraocclusion of individual teeth in the age aspect indicates the inconsistency of the data.

\section{THE AIM}

The aim of the study was to conduct a comparative assessment of the optical density of bone tissue of the alveolar process of the jaws of rats in supraocclusive relationships of individual teeth in the age aspect.

\section{MATERIALS AND METHODS}

The study was performed on 60 white laboratory rats aged 4 to 22 months weighing 150 to $330 \mathrm{~g}$. Rats were divided into control (30 individuals) and experimental (30 individuals) groups. Each group was divided into 3 subgroups (10 animals) depending on the age of rats: young, mature and senile. Young animals were rats aged 3-4 months with a weight of 90-100 g; to mature - at the age of 6-8 months with a weight of $150-170 \mathrm{~g}$; to senile rats $20-22$ months. and weighing $200-220 \mathrm{~g}$. Animals were cared for in the vivarium of the Medical Institute of the Sumy State University in accordance with the provisions of the European Convention for the Protection of Vertebrate Animals Used for Experiments and Other Scientific Purposes (Strasbourg, 1986) and compliance with the "General Ethical Rules of Animal Experiments” September 20, 2001 (Kyiv). During the experiment, the vivarium room was maintained at a constant air temperature, and rats were given proper care. Throughout the study, the animals were fed dry granulated feed, characterized by a balanced content of ingredients necessary for full life. Before the experiment, the animals were anesthetized intramuscularly with sodium thiopental solution (2 mg / kg, Thiopental, Kyivmedpreparat, PAO, Kyiv, Ukraine), approved by the Order of the Ministry of Health of Ukraine № 257 of 30.04.2015 with registration certificate № UA / 3916 / 01/01 dated 30.04.2015. In the experimental group, the state of supraocclusion was modeled by increasing the height of the lower right second molars by placing a seal $1 \mathrm{~mm}$ high. For seal was used
$37 \%$ orthophosphoric etching gel for enamel and dentin (Latus, Ukraine), microapplicators (Latus, Ukraine), fifth generation adhesive system Prime \& Bond NT (Dentsply Sirona, Germany), universal microhybrid light-curing composite material Latelux (Latus, Ukraine) and photopolymerizer LED.D (WOODPECKER, China) according to the manufacturer's instructions.

Experimental animals were removed from the experiment on day 15 by decapitation under general anesthesia with sodium thiopental. The lower jaws skeletonized, sawed jaw blocks in the molar area. Bone mineral density was determined by optical densitometry, which is widely used in medicine $[9,10,11,12]$. For densitometric studies, radiovisiography of dental blocks was performed. An aluminum test plate $0.2 \mathrm{~mm}$ thick was pre-glued to the FONA radiovisiograph sensor. Digital images were analyzed using software "ImageJ", which allows you to measure the optical density of bone tissue in any selected area of bone $[13,14]$. Quantitative determination of the optical density of the bone in the image was performed in pixels. The pixel background on radiovisiographic images of the dental blocks was calibrated on an aluminum test plate. The number of pixels in a limited area of the interradicular and interdental septa of the alveolar process of the jaws was determined. The final recalculation of the measurements was performed in conventional units, for which the average value of the pixels in the sample was divided by the value of the pixels of the test plate.

During statistical data processing, the average $(\mathrm{M})$ and its error $(m)$ were determined. The statistical significance of the difference in the two independent groups was performed according to nonparametric criteria (Mann-Whitney U-test and W-Wilcoxon test). Statistical processing was performed using the integrated package of statistical program AtteStat 12.0.5 for MS Excel. Differences at $\mathrm{p} \leq$ 0.05 were considered statistically significant.

\section{RESULTS}

For the first time, reference indicators of mineral density of the alveolar process in rats of different age groups in normal and supraocclusive relationships of individual teeth were determined (Table I).

Statistical discrepancy is present in mature and senile rats, as well as between the indicators of all rats in the control and experimental groups $(\leq 0.05)$. No significant difference was observed in young rats, but the indicators of the experimental group were $3.82 \%$ worse than in the control group. In senile rats, the density of the alveolar process decreased by $26.6 \%$, in adult rats by $17.5 \%$.

According to the results of the study, the higher optical density of the alveolar process in adult rats of the control group (3.72 \pm 0.1$)$, and lower - in young rats of the experimental group $(2.01 \pm 0.09)$. In the middle of the control group, the studied indicator in adult rats was $43.8 \%$ better than in young rats and $24.2 \%$ better than in elderly rats. In the middle of the experimental group, the rate of adult rats was $34.5 \%$ better than that of young rats and $32.6 \%$ better than that of elderly rats. 
Table I. The density of the alveolar process, conv. units $(M \pm m)$

\begin{tabular}{|c|c|c|c|c|c|}
\hline \multirow{3}{*}{ Age of rats } & \multicolumn{4}{|c|}{ A group of rats } & \multirow{3}{*}{$\mathbf{P}$} \\
\hline & \multicolumn{2}{|c|}{ Control } & \multicolumn{2}{|c|}{ Experimental } & \\
\hline & $\mathbf{n}$ & $M \pm m$ & $\mathbf{n}$ & $M \pm m$ & \\
\hline Young & 10 & $2,09 \pm 0,05$ & 10 & $2,01 \pm 0,09$ & 0,9 \\
\hline Mature & 10 & $3,72 \pm 0,1$ & 10 & $3,07 \pm 0,13$ & 0,002 \\
\hline Seniors & 10 & $2,82 \pm 0,13$ & 10 & $2,07 \pm 0,14$ & 0,008 \\
\hline Together & 30 & $2,87 \pm 0,13$ & 30 & $2,41 \pm 0,11$ & 0,016 \\
\hline
\end{tabular}

\section{DISCUSSION}

Bone remodeling is a dynamic process that begins in the early embryonic stage and continues throughout life. It is tightly regulated by osteoblasts that form bone and osteoclasts that resorb bone [15]. During aging, the regulation of bone remodeling can be disrupted, leading to a decrease in bone density and brittle bone structure [16]. In our study, we confirmed that in elderly rats, the optical density of bone tissue decreases both in the control and in the experimental groups. Simulation of the OT state led to a significant decrease in the optical density of bone tissue in rats of mature and senile age. Continuous remodeling ensures the adaptation of bone tissue to different functional loads and occurs both in the walls of the dental alveoli and in the supporting bone of the alveolar process $[17,18,19]$.

Bone tissue consists of a mineral matrix that provides rigidity and strength, and an organic matrix with collagen as the main component that provides plasticity and toughness. During aging, the concentration of collagen and minerals in bone tissue shows a reverse progression. Our research has shown a significantly higher concentration of collagen, and appropriately, lower concentration of minerals in the cancellous bone of an adolescent than in the cancellous bone of an adult [20]. Biochemical composition of the bone tissue of the alveolar processes does not differ from that in other parts of the skeleton: $45-50 \%$ of its mass are inorganic substances, $25-30 \%$ - organic, $25 \%$ - water [17]. It consists mainly of calcium and phosphorus salts. Minerals in the form of hydroxyapatite make up 65-70\% of bone structure [21].

The amount of hydroxyapatite in the mineralized part of the bone was decreasing with age [22]. It is common knowledge that mechanical stress induces the proliferation and differentiation of bone-derived cells and the synthesis of the extracellular matrix with the help of various macromolecules [23, 24, 25].

When mechanical force is applied to a bone, stress can be revealed by certain cells, which then release chemical mediators that cause bone remodeling through autocrine and paracrine mechanisms. These mechanosensitive cells are most likely osteoblasts and osteocytes. Similarly, osteoclasts in the periodontal ligament can play a key role in the cleavage of periodontal tissues under excessive occlusal loading [26].

When an occlusive trauma is combined with inflammation, it causes degeneration of collagen fibers and is likely to increase antigen permeability. Then, the immune complex spreads, and the infiltration of inflammatory cells connected with tissue destruction increases [27].

In our study, we simulated the TO state without inflammation and after considering the results we see a significant decrease in optical density in mature and senile rats $(\leq 0.05)$.

\section{CONCLUSIONS}

The presence of supraocclusive relationships of individual teeth causes a decrease in bone density of the alveolar process of the jaws in rats.

The greatest loss of density among age groups in elderly rats.

Prospects for further research - to study the morphological changes in the tissues of the teeth and periodontium in the supraocclusive relationship of individual teeth in the age aspect.

\section{REFERENCES}

1. Dzampaeva Zh. V. Osobennosti etiologii i patogeneza vospalitelnykh zabolevanii parodonta [Features of the etiology and pathogenesis of inflammatory periodontal diseases] Kuban Scientific Medical Bulletin. 2017;5(24):103-110. (In Russian). doi: 10.25207/1608-6228-2017-245-103-110.

2. Naumovich S. S., Drick F. G. Biomekhanicheskiie svoistva kompleksa «zyb - periodontalnaia sviazka - kostnaia tkan» v veksperimente [Biomechanical properties of the complex "tooth - periodontal ligament - bone" in experiment]. Modern Dentistry. 2017;2:58-61 (In Belarus).

3. Ben-Zvi Y., Maria R., Pierantoni M. et al. Response of the toothperiodontal ligament-bone complex to load: A microCT study of the minipig molar. Journal of Structural Biology. 2019;205(2):155-162. doi: 10.1016/j.jsb.2019.01.002.

4. Kniazeva M. A. Okkkiuzionnaia travma. Uchebno-metodicheskoie posobiie. [0cclusal trauma. Study guide]. Vitebsk:VGMU; 2012, 9 p.

5. Domeniuk D. A., Davydov B. N., Vedeshina E. H. et al. Kompleksnaia otsenka arkhitektoniki kostnoi tkani i hemodinamiki tkanei parodonta u ditiei s zybocheliustnymi anomaliiami [Comprehensive assessment of the architectonics of bone tissue and hemodynamics of periodontal tissues in children with dentoalveolar anomalies]. Pediatric dentistry and prevention. 2016;3(15):41-48. (In Russian).

6. Bimbas Ye.S., Zakirova T.V. Osnovnoie ortodontichieskoie liechieniie patsiientov s zabolievaniiami parodonta [The main orthodontic treatment for patients with periodontal disease]. DentalMagazine. 2013;27:17-21. (In Russian).

7. Sanadi R. M., Chelani L. R., Bhakkand S. R. et al. Role of trauma from occlusion in periodontal disease-A controversy. IOSR-J Dent Med Sci. 2016;15:118-222. doi: 10.9790/0853-150904118121. 
8. Khoroshilkina F.Ya., Soldatova L. N., Iordanishvili A. K. Osobennosti fonietichieskoi rieabilitatsii molodykh liudiiei, stradaiushchykh zybocheliustnymi anomaliiami i prokhodiashchimi ortodontichieskoie liechieniie [Features of phonetic rehabilitation of young people suffering from dentoalveolar anomalies and undergoing orthodontic treatment]. Orthodontics. 2017;4(80):6-10. (In Russian).

9. Fisher E., Austin D., Werner H. M. et al. Hyoid bone fusion and bone density across the lifespan: prediction of age and sex. Forensic Sci Med Pathol. 2016;12:146-157. doi: 10.1007/s12024-016-9769-x.

10. Mosegaard S. B., Mosegaard K. B., Bouteldja N. et al. Trapezium bone Density-A comparison of measurements by DXA and CT. Journal of Functional Biomaterials 2018;9(1):9. doi: 10.3390 / jfb9010009.

11. Kuroedova V., Vyzhenko E., Makarova A. at al. Optical density of upper jaw in patients with malocclusion. Widomosci Lekarskie. 2017;5:913-916.

12. Akhoundi M. S. A., Sheikhzadeh S., Mirhashemi A. at al. Decreased bone density induced by antiepileptic drugs can cause accelerated orthodontic tooth movement in male Wistar rats. International orthodontics. 2018;16(1):73-81. doi: 10.1016/ j.ortho.2018.01.021.

13. Yasar F., Apaydin B., Yilmaz H.H. The effects of image compression on quantitative measurements of digital panoramic radiographs. Med. Oral Patol. Oral Cir. Bucal. 2012;17(6):1074-1081. doi:10.4317/ medoral.17912.

14. de Assis A.C.S., de Oliveira Gamba T., de Moraes M.E.L. at al. Hormone replacement therapy affects mandibular bone architec- ture in postmenopausal women: a fractal dimension assessment. Rheumatol. Orthop. Med. 2017;1(2):1-4. doi: 10.15761/ROM.1000111.

15. Florencio-Silva R. et al. Biology of bone tissue: structure, function, and factors that influence bone cells. BioMed research international. 2015. doi: $10.1155 / 2015 / 421746$.

16. Becerikli M., Jaurich H., Schira J. at al. Age-dependent alterations in osteoblast and osteoclast activity in human cancellous bone. Journal of cellular and molecular medicine. 2017;21(11):2773-2781. doi: 10.1111/ jcmm.13192.

17. Oriekhova L.Yu. Funktsionalnaia morfologia poddierzhyvaiushchiego apparata zuba. In: Oriekhova L.Yu. Zabolevaniia paradonta. Moskva: Poli Media Press; 2004 7-57 p.

18. lezzi G., Mangano C., Barone A. et al. Jawbone remodeling: a conceptual study based on Synchrotron High-resolution Tomography. Scientific reports. 2020;10(1):1-12.

19. Feller L., Khammissa R. A. G., Schechter I. Biological events in periodontal ligament and alveolar bone associated with application of orthodontic forces. The Scientific World Journal, 2015. https://doi. org/10.1155/2015/876509.

20. Ding M., Danielsen C.C., Hvid I. etal. Three-dimensional microarchitecture of adolescent cancellous bone. Bone. 2012;51:953-60. doi 10.1016/j. bone.2012.07.018.
21. Gudianov A.I. Etiologiia I patogenez vospalitielnykh zabolievanii parodonta. In: Gudianov A.I. Zabolievaniia parodonta. Moskva: Meditsinskoie informatsionnoie agenstvo; 2009, 9-14 p.

22. Wang X., Hua R., Ahsan A. at al. Age-related deterioration of bone toughness is related to diminishing amount of matrix glycosaminoglycans (GAGs). JBMR plus. 2018;2(3):164-173. doi 10.1002/jbm4.10030.

23. Sodeyama T., Maeda T., Takano Y. et al. «Responses of periodontal nerve terminals to experimentally induced occlusal trauma in rat molars: an immunohistochenmical study using PGP 9.5 antibody.» Journal of periodontal research 1996;31(4): 235-248.

24. Nomura S., Takano-Yamamoto T. Molecular events caused by mechanical stress in bone. Matrix Biol 2000;19:91-96.

25. Ehrlich P.J., Lanyon L.E. Mechanical strain and bone cell function: a review. Osteoporos Int 2002;13:688-700.

26. Takeo F. et al. Experimental Model of Occlusal Trauma in Mouse Periodontal Tissues. Journal of Hard Tissue Biology, 2014;23(3):377-380.

27. Nakatsu $S$. et al. Occlusal trauma accelerates attachment loss at the onset of experimental periodontitis in rats. Journal of periodontal research, 2014;49(3):314-322.

\section{ORCID and contributionship:}

Yurii V. Lakhtin: 0000-0001-5055-3162 A,F

Serhii M. Zviahin: 0000-0001-8232-4049 ${ }^{B, C, D, E}$

Lidia M. Karpez: 0000-0003-4782-4165 D,E

\section{Conflict of interest:}

The Authors declare no conflict of interest.

\section{CORRESPONDING AUTHOR Serhii M. Zviahin \\ Sumy State University \\ 31 Sanatorium st., 40000 Sumy, Ukraine \\ tel: +380661457570 \\ e-mail:s.zvyagin@med.sumdu.edu.ua}

Received: 08.09.2020

Accepted: 02.06.2021

A - Work concept and design, B - Data collection and analysis, C - Responsibility for statistical analysis,
D-Writing the article, $\mathbf{E}$ - Critical review, F - Final approval of the article 